\title{
TREATMENT PROGRAMS FOR SPECIFIC GROUPS OF PRISONERS - JUVENILES AND THE PERMANENTLY UNEMPLOYABLE
}

\author{
Stanislava Hoferková, Tereza Raszková
}

\begin{abstract}
This paper focuses on the issue of the treatment of specific groups of convicts, especially on juveniles and the permanently unemployable. The article defines the issues of penitentiary treatment, including treatment programs and their activities (work, education, leisure, special educational activities, forming external relationships). It describes the issues of a specific group of prisoners, brings a close look at juvenile convicts and the permanently unemployable who include persons over 65 years of age or ill persons. This paper aims to describe the specifics of treatment for these groups of inmates.
\end{abstract}

\section{Keywords}

incarceration, treatment program, specific group of convicts, juveniles, permanently unemployable

\section{Introduction}

The body ensuring the enforcement of incarceration sentences, custody and security detention in the Czech Republic is the Prison Service of the Czech Republic (established in 1993 through Act no. 555/1992 Coll., on the Prison Service and Judicial Guard of the Czech Republic). Treatment of imprisoned persons must respect fundamental human rights, unless the law itself suspends them by incarceration sentence or enforcement of custody, and to maintain the health of the inmates - physical, mental and social. The Czech Republic has to follow the recommendations contained in the European Prison Rules; the basic principles include an emphasis on the re-socialization of individuals: "The service of a sentence shall be managed so as to enable persons deprived on liberty the reintegration into the free society." (European Prison Rules, 2006, p. 3). The emphasis on the pursuit of social rehabilitation is especially common with modern European states and reflects the historical and cultural development and religious beliefs. The pragmatic reason is the fact that in the absence of a capital punishment (i.e. a life sentence with the impossibility of release or the death penalty), penology has to consider that the incarcerated individual will be released one day (apart from the extreme cases 
of deaths in prison). Therefore, it is necessary to make an effort to re-socialize the convict or at least not to harm him/her with the prison conditions.

For the above reasons, the so-called treatment program (formerly re-socialization program) is implemented during the enforcement of the sentence. Treatment programs are also "tailored" to the specific needs of different groups of inmates.

This paper characterizes the treatment program; further pays attention to specific groups of convicts - juveniles and permanently unemployable (henceforth as PU), who include e.g. the elderly. These two groups are different at first glance, but their developmental specifics bear the same features, which largely determines the possibilities and needs of the treatment.

\section{Treatment of Imprisoned Persons}

Already in the nineteenth century, Father Francis Joseph Řezáč emphasized complex influence on and education of convicts and also pointed to the importance of after-care. In the $21^{\text {st }}$ century there are already well-developed treatment programs, including various projects to reduce recidivism and allow for an easier reintegration into normal life.

Černíková (2008, pp. 143-144) defines treatment as "a summary of activities directed at the perpetrators of crimes, carried out by specialized personnel (educational, penitentiary, social services) who deal with the criminal offenders, address and help solve their problems, lead the convicts (to work, to education, to independence, ...), provide care (for their health, positive development), exercise influence, affect their behaviour, opinions, development - towards a prosocial orientation. The aim is that the content of the treatment leads the convicts to socially more mature - more responsible behaviour." In a prison environment, basically two types of methods may be implemented: general methods which respect the pedagogical principles (the regime method, the rewards and punishments method, the natural consequences method, persuasion, etc.), or special methods which combine special-pedagogical, psychological, psychiatric and other procedures (e.g. special therapeutic programs).

An important role in the reform the offender is played by the factor of time which the individual spends in a prison facility. The longer the stay in prison, the more one is disturbed by the prison subculture, often leaving prison "enriched" by a wide range of knowledge that leads to further and more effective crime. The entire process of treatment should be directed towards three main objectives (Černíková, Makariusová, 1996):

1. Cultivation of habits through further education - which means actual professional training, retraining, lifelong learning, leisure education, development interests and hobbies, quality use of leisure time, etc.

2. Acquisition of appropriate social skills for re-adaptation into life outside prison - primarily aimed at maintaining social ties.

3. Specific assistance and expertise aimed at solving personal problems (debt counselling, divorce and after-divorce care, legal advice, administration of old age, invalidity, widow and orphan pensions, etc.).

The treatment is then subject to many factors, such as the prison environment and the nature of fellow inmates, the personnel, the length of incarceration, but also, of course, the personality of the 
inmate - coping with stressful situations, previous experience, psychiatric and other pathological load (personality disorders, substance abuse) and their social background, motivation to change, etc. It is clear that the treatment itself is influenced by many factors, and only some can be influenced by the personnel of the Prison Service.

Based on a comprehensive assessment of the convict, a suitable treatment program is elaborated. Programs are compiled from individual activities based on the possibilities of the prison and respecting the personality characteristics, social situation, length of sentence, the causes of criminal activity and the interests of the prisoner. A treatment program, then, contains specifically defined objectives of affecting the imprisoned individual, the methods of the treatment of he convict, methods aimed at achieving the goals, and the methods and frequency of assessment. An integral part of a treatment program with the employable convicts is occupational therapy. Offering alternatives of treatment programs, the incarceration facility is required to use the widest variety of forms, methods and means which require active approach on the part of the convicts and contain elements of self-service. Programs of treatment of convicts have the following components (Raszková, Hoferková, 2014):

a) working activities,

b) educational activities,

c) special educational activities,

d) leisure activities,

e) shaping the area ofexternal relations.

The working program activities include employment in the premises of the incarceration facility or outside the premises, work needed for the provision of daily operation of the facility (daily cleaning, maintenance, etc.) and occupational therapy. Determining working activities, the convicts' training and gained experience in a specific field, health, the amount of debts, the motivation to work and the length of the sentence are taken into account. Tax and payments for social security and health insurance are deduced from the convicts' remuneration for the work performed. Subsequently, further deductions are carried out, e.g. to cover the maintenance costs of imprisonment, the cost of legal proceedings, seizure of assets, payment on remand, the claims of the injured party etc. Working activities are an important component of the treatment, as they bring not only financial but also relaxing, educational, correctional and other benefits. It helps many convicts to structure their time in prison and to meaningfully fill the large amount of their free time. Unfortunately, it is the permanently unemployable whose treatment program does not include working activities, but it is possible to use e.g. occupational therapy methods, emphasizing self-service activities. Educational activities are also preferred with juveniles.

Education of prisoners is anchored not only in legislative acts, such as the Charter of Fundamental Rights and Freedoms, the Imprisonment Act, regulations on serving imprisonment sentences, or internal regulations governing the treatment of prisoners, but relies also on international documents, such as the European Prison Rules. The convict can be educated at a school education centre which offers various training courses, completion of primary education, vocational, general educational and other courses (the Secondary vocational school is an organizational unit of the Prison Service with headquarters in Prague, branch offices are in prisons in Pardubice, Opava, Světlá nad Sázavou, Valdice, Plzeň [Pilsen], Rýnovice, Všehrdy and Kuřim). Educational activities 
further include education realized by the personnel of the department of the sentence term service (language courses, socio-legal courses, courses in civics, basics of PC operation, etc.), or education in correspondence courses and in the network of primary and secondary schools, colleges and universities in the Czech Republic.

One of very interesting practices is the therapeutic work with prisoners. However, the fact is that it is a procedure of low efficiency, not bringing any results that would match the effort. Effective therapeutic work must be based on the specific problems of individual persons. Under these circumstances, it is not possible to mechanically apply the usual psychotherapeutic approaches. Individual special educational activities are primarily led by educators - therapists. One of the main tasks of special education procedures is a differentiated treatment of convicts, especially of the risk groups of prisoners. These include the following activities: art therapy and art techniques, relaxation techniques, drama therapy, occupational therapy, group therapy for drug addicts, group therapy for young convicts. The mentioned activities play an important role in the treatment of juvenile convicts and the PU.

Interest activities of the treatment program refer to all forms of individual and group leisure activities organized and conducted by the staff with the necessary professional education (educators - therapists, special educators, social workers and educators). The topical offer of interest activities corresponds to the material and spatial possibilities of the incarceration facility.

The activities in the field of shaping external relationships are all activities that contribute to the preparation for independent living with which the convicts have to cope after their release. The basic elements of these activities include: maintaining ties with close persons, handling the basic documents during or before the end of the sentence (identity cards, citizenship of the Czech Republic), cooperation with the Probation and Mediation Service of the Czech Republic and other state and non-state entities. Especially with juveniles, emphasis is laid on maintaining ties with their family members who should be an integral component of the re-socialization of the juvenile. Unfortunately, the family may also have a negative impact on the convict (see eg. Raszková, Hoferková, 2012) - in case of a juveniles, a dysfunctional family may be one of the reasons for crime to occur.

The treatment programs can be effective only if the convicts are somehow motivated and willing to take part in the programs and fulfil them. The treatment of convicts cannot be generalized because each convict is an individual and has his/her own specific needs, depending on age, length of sentence, social contacts and the number of previous arrests.

Tregler (2004, p. 13) notes that "the effectiveness of treatment programs is directly dependent on the conditions in which they are implemented. In many places, these conditions are very limited and usually do not correspond to the needs of either the inmates or the workers in charge. For example, we have limited space, material resources and we often encounter the lack of professionalism on the part of prison staff. However, the success of treatment programs depends mostly on the personality of the convict, his or her attitudes and interests. In practice, it quite often happens that the convicts are not interested in a wide range of leisure-time educational and therapeutic activities, which is especially true of men." The pitfall is also in the treatment of specific groups of convicts who cannot participate in some activities (e.g. the permanently unemployable) or represent a higher risk in terms of safety or require special handling (e.g. juveniles). 
In the prison environment there are many factors which impede or directly interfere with the treatment of convicts. These are so-called barriers to the implementation of treatment programs and they include the so-called. prisonisation, the "second life of convicts" and the prison staff (see e.g. Raszková, Hoferková, 2014a, 2014b; Sochůrek, 2007b).

\section{Specific Groups of Convicts}

Many differences applied in the enforcement of incarceration sentences can be found already in the standards of imprisonment, especially in the Act on Imprisonment, in the regulations on serving imprisonment sentences and the uniform internal rules of prisons. At the same time, diverse regulations of the director general or department director(s) are issued, focusing on the treatment of particular specific group. The differentiation of inmates is one of many factors that support treatment of convicts, facilitate the work of the Prison Service of the Czech Republic and assists the work of other entities which cooperate closely with the Prison Service (e.g. the courts, police). Specific groups of convicts include according to Act on Imprisonment (Act no. 169/1999 Coll.) especially juveniles, women, mothers of minors, permanently unemployable convicts, convicts with mental and behavioural disorders, convicted foreigners and very dangerous persons. For all these groups, the age, psychological and physiological peculiarities are taken into account. Other specific groups include convicts from the environment of organized crime or terrorists. For each of these groups, individual approach needs to be applied more than anywhere else.

According to Sochůrka (2007a), we may find people serving incarceration sentences who in psychological terms both do not depart from the norm, and who suffer from severe behavioural disorders, personality disorders, sexual deviations, decreased intellect, or other various problems, whether temporary or permanent in nature. Also, there are convicts with sensory, intellectual or physical disabilities, neurotics, persons with a long-term addiction to alcohol or other addictive substances, and convicts from the organized crime scene. The above mentioned groups of convicts are mostly either placed in separately set-up specialized departments, or subject to specialized treatment.

\subsection{The Incarceration Sentence Punitive Measures of Juveniles}

A juvenile is an individual aged 15 to 18 years, whose criminal liability is reduced, unlike that of an adult. Criminal acts of juveniles are regulated by Act no. 218/2003 Coll., on Juvenile Justice; under this Act, a juvenile may be sentenced to educational, protective or punitive measures.

Proceedings in juvenile cases should be led with regard to their age, state of health, mental and moral maturity, so as not to disrupt their psyche and in view of their age, not to jeopardize their future mental and social development. When discussing the unlawful acts of the youth, the following is especially attempted (Act no. 218/2003 Coll.):

- to use such a measure which will lead to the reform of the offender,

- to take into account the possibilities of the future social application of the individual which would correspond to his or her abilities and intellectual development of a young person and thus contribute to his or her adequate participation in the society, 
- to ensure that the measure is educational in nature, i.e. that the individual contributes, according to his or her strength and ability, to atone the damage suffered by the wrongful act,

- to conduct the proceeding itself so as to contribute to the prevention of the commission of criminal acts.

Within the punitive measures, juveniles can be sentenced to e.g. the punitive measure of imprisonment without probation, while the length of imprisonment prescribed by the Criminal Code is reduces for juveniles by half and the maximum penalty may not exceed five years and the minimum one year. If a juvenile commits an offence for which the Criminal Code provides for an exceptional sentence or the degree of danger of such wrongdoing is extremely high, the juvenile court may sentence the juvenile to five to ten years of incarceration.

The juvenile incarceration facilities are for convicts aged 15 to 18 years. This time, can be extended (most often to 19 years of age) given the length of the sentence and personality traits. Then, the convict of near juvenile age is reassigned among adult convicts upon a proposal of the prison director. The department for female juvenile convicts is established in Prison Světlá nad Sázavou, the department for juvenile male convicts is established in Pardubice Prison, Všehrdy Prison and Heřmanice Prison.

The treatment of juvenile offenders is very specific, as it must take into account the mental, moral and social maturity, the degree of danger and possibility of rectification. Authors Černíková and Sedláček (2002, p. 58) summarize the issues as follows: "Effective methods of dealing with juvenile inmates form a specific penitentiary category. Generally, most agree that a juvenile convict is more flexible and accessible to educational influences and the re-socialization process of juveniles is more promising, though not always easy. An essential penological aspect of working with juveniles is a very deep understanding of their psychological and personality traits and characteristics, and finding the most optimal, effective educational approach to reformulation of the criminalized personality structures."

With juveniles, very sensitive and attentive approaches need to be applied, we should try to offer them pro-social models for their future conduct. It is important to clarify what is attractive to the adolescent, what is his/her hierarchy of values, what is his/her status among peers, whether s/he has any talents, abilities, how s/he seeks sexual partners, what s/he sees the meaning of life in, how s/he reproduces the peer opinions, and how s/he hypercritically evaluates opinions of the parents, teachers, or "older" population. The techniques and methods that are used in working with adolescents include techniques of self-knowledge, exercise of communication skills, model situations, psychodrama, assertiveness, empathy, non-verbal communication, creation of a value chain, managing aggression and more.

For juvenile convicts, individual treatment is applied in an increased way to focus on developing the intellectual, emotional and social maturity of juveniles. Emphasis is placed on acceptance of personal responsibility for the wrongdoing committed, strengthening the independent solutionseeking in life situations, control and management of aggressive reactions and of inappropriate behaviour. Educational and work activities are focused on acquiring knowledge and skills which would help the juvenile to work after returning from prison. The juveniles are led to such leisure activities that meet their developmental needs. (Decree no. 345/1999 Coll., issuing the regulations on serving imprisonment sentences). An important aspect of dealing with juveniles is the security of their preparation for a future career (the form and content of the future occupations is consult 
with the legal representatives of the juvenile and with the competent authority for social and legal protection of children). In the event that a juvenile is to fulfil compulsory education, it is prioritized over a job.

A specific difference is the prohibition of television viewing and possession of material with pornographic content, as well as the prohibition of buying tobacco products. If juveniles live in cells, they are being locked from lights-out to reveille.

A specific problem is adolescent sexuality. For convicts in this age group, sexuality and relationships with the opposite sex are a very important and sensitive issue. In the group, there are individuals who had inappropriate role models (domestic violence between parents), committed vice crimes (sexual offences), are personally and emotionally immature, or, conversely, are already parents. Substitute sexual gratification in prison may have a pathological character in the form of sexual harassment or abuse of fellow inmates. It is therefore important to talk to adolescents about these topics, not to moralize or trivialize, allow for adequate sexual satisfaction (masturbation) and especially, not to make taboos.

In 2013, a total of 1,593 juveniles were convicted. Vast majority of juveniles were sentenced to these measures (Report on Public Order and Internal Security in the Czech Republic in 2014, compared with 2013, 2015, p. 17):

- incarceration, suspended for a probationary period - 976 juveniles,

- community service -269 juveniles,

- incarceration measure without probation - 88 juveniles,

- in case of 250 juveniles, punishment was abandoned.

As shown in the following Table no. 1, as to December 31, 2014, there were 82 convicted juveniles in Czech prisons, of whom 77 were boys and 5 were girls.

Table no. 1 The number of convicted juveniles between 2004 and 2014 (as to December 31.)

\begin{tabular}{|l|r|r|r|r|r|r|r|r|r|r|r|}
\hline Year & $\mathbf{2 0 0 4}$ & $\mathbf{2 0 0 5}$ & $\mathbf{2 0 0 6}$ & $\mathbf{2 0 0 7}$ & $\mathbf{2 0 0 8}$ & $\mathbf{2 0 0 9}$ & $\mathbf{2 0 1 0}$ & $\mathbf{2 0 1 1}$ & $\mathbf{2 0 1 2}$ & $\mathbf{2 0 1 3}$ & $\mathbf{2 0 1 4}$ \\
\hline Male & 96 & 120 & 109 & 133 & 148 & 166 & 142 & 150 & 134 & 77 & 77 \\
\hline Female & 6 & 4 & 2 & 1 & 4 & 8 & 9 & 9 & 6 & 4 & 5 \\
\hline Total & $\mathbf{1 0 2}$ & $\mathbf{1 2 4}$ & $\mathbf{1 1 1}$ & $\mathbf{1 3 4}$ & $\mathbf{1 5 2}$ & $\mathbf{1 7 4}$ & $\mathbf{1 5 1}$ & $\mathbf{1 5 9}$ & $\mathbf{1 4 0}$ & $\mathbf{8 1}$ & $\mathbf{8 2}$ \\
\hline $\begin{array}{l}\text { The percentage } \\
\text { of juveniles on } \\
\text { the total number } \\
\text { of convicts }\end{array}$ & $.68 \%$ & $.77 \%$ & $.69 \%$ & $.80 \%$ & $.84 \%$ & $.90 \%$ & $.78 \%$ & $.77 \%$ & $.69 \%$ & $.57 \%$ & $.50 \%$ \\
\hline
\end{tabular}

Source: Statistical Yearbook of the Czech Prison Service, 2014. In The Prison Service of the Czech Republic. [online]. Prague, 2015, p. 117.

The percentage of juveniles convicted in relation to adults is relatively small - the juveniles account for only $0.5 \%$ of all convictions (the total number of convicts as to the last day of 2014 amounted to 16,433 persons). Number of accused juveniles in custody as to December 31, 2014 was 24 boys and 1 girl (from a total of 2,185 defendants). 
Table no. 2 Incarcerated persons as to August 1, 2015

\begin{tabular}{|l|c|c|c|}
\hline \multicolumn{2}{|c|}{ Imprisonment of juveniles } & \multirow{2}{*}{$\begin{array}{c}\text { Total number } \\
\text { of inmates }\end{array}$} \\
\hline Custody enforcement & Boys & Girls & 5 \\
\hline Incarceration sentence service & 15 & 1 & 1,944 \\
\hline Security detention enforcement & 86 & 0 & 18,348 \\
\hline Total Juveniles & $\mathbf{1 0 1}$ & $\mathbf{6}$ & $\mathbf{2 0 , 3 4 6}$ \\
\hline
\end{tabular}

Source: Quick Facts. Conditions of prisoners Vscr.cz In The Prison Service of the Czech Republic. [online]. (C) 2012 last update August 26, 2015.

As to August 1, 2015, there were a total of 107 juveniles in Czech prisons (in custody and serving incarceration measures; Tab. 2). A total of 20 juveniles were in prison custody, and 87 juveniles were serving an incarceration measures (already 5 more juveniles than at the end of 2014). No juvenile has been placed in security detention.

\subsection{Permanently Unemployable Convicts}

A permanently unemployable convict is a convicted person older than 65 years (unless s/he requested assignment of a job), a person with the recognized third-degree disability, or a person whose state does not allow for permanent employment (Act no. 169/1999 Coll., on Imprisonment). This issue is closely related to the health classification which expresses the convict's ability to satisfy the health requirements associated with the assignment of a job without the occurrence or aggravation of the illness and without risk to the health of other persons. In an overwhelming majority of cases of PU convicts, the medical classification is "F" (convicts who are waiting for the physician's statement regarding the change to the classification " $\mathrm{N}$ " form an exception).

With increasing age, prevalence of diseases with the elderly increases. The illnesses associate so that several diagnoses often occur with an individual at the same time. The seniors' mental activity is slowing down, they have weaker incentives, are sensitive to changes and increasingly cautious. Their psychomotor pace is slowing down, their imagination is impoverished, emotions are unstable, vitality and energy are declining, there is a lower concentration of attention, there is a reduction in the recollection and retention of memory. (Mühlpachr, 2004; Zavázalová, 2001).

Compliance with basic hygiene habits becomes a great problem. Many of the inmates suffer from incontinence (urine and stool), are unable to bathe or dress themselves. The PU convicts who are immobile and less mobile are provided with the help of the so-called health assistants.

In the case of PU convicts, their health status is especially taken into account and in this context, they are provided the necessary medical care. Unlike the standard sentence service conditions, there are no bunk-beds in the PU dormitories and their bathroom is not locked. The number of inmates in dormitories is around five to six persons, also bedrooms for the immobile are set up.

Treatment programs for permanently unemployable (PU) Convicts are primarily focused on their autonomy and self-sufficiency. Of course, we have to take into account the differences corresponding to 
the basic characteristics of this specific group. They differ especially in health, age, the degree of disorder and also the mental state of the individual. Three programs of treatment which are assigned to convicts in Pardubice Prison are presented below. One of the men is a young adult, the next one is of productive age and the last one is a senior. All of these individuals are assigned to a specialized department for permanently unemployable (other attributes are not listed due to protection of the anonymity of the respondents).

Convict A. B., senior, first incarceration, crime of violent nature.

The goal of the treatment program is focused on self-serving activity and the maintenance of family ties. In the context of working activities, the convict should maintain order in the bedroom and in his personal belongings. Educational activities are not assigned, special educational activities are not required. In the context of extracurricular activities, he is to participate in social games club under the tutelage of a tender. In the context of extramural activities, he should try to maintain contact with his family members. The program of treatment is being fulfilled for the most part in a gradual manner, especially with regard to the medical condition. He can manage most of the activities only with the participation of a health assistant.

Convict B. C., productive age, recidivist, property crime and crime of violent nature.

The goal of the treatment program is focused on compliance with the standards of self-discipline and discipline; maintenance of social ties and a change in his view on drug abuse. In the context of work activities, he should be involved in regular cleaning work at the section. No special educational or training activities have been assigned. In the context of extracurricular activities, he is to participate in social games club under the tutelage of a tender. Visiting and correspondence contact in the context of the formation of external relationships should be maintained with his sibling. The treatment program is being fulfilled.

Convict D. E., young adult, recidivist, property crime and crime of violent nature.

The goal of the treatment program is focused primarily on the personality development of the convict, on creating critical a view of his inappropriate behaviour, internal discipline towards the observance of normative acts governing the sentence service. In the context of working activities, he should focus on self-serving activity and keeping order in his personal belongings and the bedroom. No special educational or training activities have been assigned. In the context of extracurricular activities, he is to participate in social games club under the tutelage of a tender. Written and visiting contact should be maintained with his family members. The convict does not fulfil his treatment program, and has been repeatedly subjected to disciplinary punishment.

In the implementation of the research for the publication "Education and Re-Education of Permanently Unemployable Inmates of Czech Prisons" (Raszková, Hoferková, 2015, in print), we have noticed that a large number of male convicts feel a great need for a good quality of the ways time is spent in prison. Many of them yearn for daily activities resembling their everyday life, especially some outdoor activities (for instance, they would like to sweep and collect leaves, do light manual work, loosen the soil at patches, go for a walk). Their life is losing purpose, some of them are fully aware that they will not see free life again (whether with regard to the length of their sentence or to the poor prognosis of their health status). This is probably why the need for something meaningful 
to do, something to leave behind, is increasing. But due to the degree of classification (in the vast majority "F"), it is not possible to assign jobs to them (or to work without remuneration).

A special chapter then consists of individuals with mental disorders. If they are not capable (or willing) to cooperate with the employees on fulfilling the purpose of the enforcement of the sentence, they are only being detained in prison. At the same time, large tension arises in the dormitory because of their irregular behaviour (autistic inmates, deaf-mute, nonconformist conducts - biting, spreading feces, etc.). Some disabled also have problematic behaviour, as they sometimes commit spiteful actions aimed at the other inmates or medical assistants (breaking health aid instruments or not wanting to lend them to the others).

\section{Conclusion}

The issues of the treatment of specific groups of convicts lies at the centre of the interest of many professionals, including penologists, and they require a trans-disciplinary character. In this paper, we have presented two groups of persons who are according to the Act on Imprisonment sorted into the specific groups of juvenile convicts and permanently unemployable convicts. On the surface, these groups are different but their common denominator lies in age-related developmental peculiarities. Juvenile inmates are often mentally, emotionally and socially immature, however, they have often committed serious crimes (juveniles are preferably sentenced to alternative punishment, if the character of the committed offence and thus their social dangerousness allow so). Their sexuality poses a great problem which, however, often becomes a taboo (this issue is not very often referred to in professional publications or research).

On the other hand, there are senior convicts and ill or handicapped inmates who are not capable of working. These groups belong among the permanently unemployable. These persons, particularly the elderly, are characterized by a well-formed register of attitudes and values, with a wealth of life experiences. The problem for these groups of persons is not only the care for their health, but also their leisure options which are subject to their age and state of health.

Adequate treatment with incarcerated persons should on the one hand respect the basic human rights, on the other hand, it should fulfil the social need for the rectification and subsequent resocialization of the offender. It should be borne in mind that the Prison Service of the Czech Republic often has limited options due to the prison environment alone. It appears that many of the projects which apply to different groups of inmates are efficient (e.g. Program $3 \mathrm{Z}$ ). The greater differentiation of inmates according to their degree of criminal experience, social dangerousness or specific needs seems efficient as well.

\section{References}

Act No. 169/1999 Coll., on Imprisonment, as amended.

Act No. 218/2003 Coll., on Juvenile Justice, as amended by Act No. 41/2009 Coll., as amended.

Act No. 555/1992 Coll., on the Prison Service and Judicial Guard of the Czech Republic, as amended. 
Černíková, V. et al. (2008). Sociální ochrana: terciární prevence, její možnosti a limity. [Social Protection: Tertiary Prevention, Its Possibilities and Limits]. Plzeň: Vydavatelství a nakladatelství Aleš Čeněk, s.r.o. [Editing and Publishing House Aleš Čenek, Ltd.].

Černíková, V., \& Makariusová, V. (1996). Sociální ochrana. [Social protection]. Prague: Police Academy of the Czech Republic.

Černíková, V., \& Sedláček, V. (2002). Základy penologie pro policisty. [Introduction to Penology for Police Officers]. Prague: Police Academy of the Czech Republic.

Decree No. 345/1999 Coll. issuing the regulations on serving imprisonment sentences, as amended.

Evropská vězeňská pravidla: doporučení REC (2006)2 Výboru ministrů členským státům Rady Evropy k Evropským vězeňským pravidlům. [The European Prison Rules: Recommendation REC (2006) 2 of the Committee of Ministers to the Member States of the Council of Europe on the European Prison Rules]. [online]. http://www.vscr.cz/client_data/1/user_files/19/file/PDF/Publikace/ Evropsk\%C3\%A1\%20v\%C4\%9Bze\%C5\%88sk\%C3\%A1\%20pravidla.pdf.

Mühlpachr, P. (2004). Gerontopedagogika. [Gerontopedagogy]. Brno: Masaryk University.

Quick Facts. Stavy vězněných osob. [Conditions of Imprisoned Persons]. [online]. Accessed $5^{\text {th }}$ August 2015. http://www.vscr.cz/generalni-reditelstvi-19/informacni-servis/rychla-fakta/.

Raszková, T., \& Hoferková, S. (2012). Vliv rodiny na jedince ve výkonu trestu odnětí svobody. [The Influence of the Family on an Individual Serving an Imprisonment Sentence]. In S. Hoferková, (Ed.), SOCIALIA 2012. Rodina a sociálně patologické jevy. [The Family and Socio-Pathological Phenomena]. Hradec Králové: Gaudeamus, pp. 77-87.

Raszková, T., \& Hoferková, S. (2014a). Kapitoly z penologie II. [Chapters from Penology II.]. Hradec Králové: Gaudeamus.

Raszková, T., \& Hoferková, S. (2014b). Rizikové chování ve věznicích. [Risk Behaviour in Prison]. In H. Válková, V. Černíková, \& J. Firstová et al. (Eds.), Aktuální otázky vězeňství. [Current Issues in the Prison System]. Prague: Police Academy of the Czech Republic in Prague, pp. 63-71.

Raszková, T., \& Hoferková, S. (2015). Edukace a reedukace trvale pracovně nezařaditelných v českých věznicích. [Education and Re-Education of the Permanently Unemployable in Czech Prisons]. Hradec Králové: Gaudeamus. In press.

Sochůrek, J. (2007a). Kapitoly z penologie. [Chapters from Penology]. II. díl, Teorie a praxe zacházení $s$ vězněnými. [Part II., Theory and Practice of the Treatment of Prisoners]. Liberec: Technical University in Liberec.

Sochůrek, J. (2007b). Kapitoly z penologie. [Chapters from Penology]. III. díl, Negativní jevy ve vězení. [Part III., Negative Phenomena in Prison]. Liberec: Technical University in Liberec.

Statistical Yearbook of the Prison Service of the Czech Republic 2014. [online]. Accessed $5^{\text {th }}$ August 2015. http://www.vscr.cz/client_data/1/user_files/19/file/spr\%C3\%A1vn\%C3\%AD/ statistiky/Statistick\%C3\%A9\%20ro\%C4\%8Denky/Rocenka_2014.pdf. 
Tregler, J. (2004). O českém vězeňství u kulatého stolu. [On The Czech Prison System at a Round Table]. České vězeňství [The Czech Penitentiary System], 12(5), pp. 12-15.

Zavázalová, H. (2001). Vybrané kapitoly ze sociální gerontologie. [Selected Chapters from Social Gerontology]. Prague: Karolinum.

Zpráva o situaci v oblasti veřejného pořádku a vnitřní bezpečnosti na území České republiky v roce 2014 (ve srovnání s rokem 2013). [Report on Public Order and Internal Security in the Czech Republic in 2014 (compared with 2013)]. [online]. Accessed $5^{\text {th }}$ August 2015. http://www.mvcr.cz/clanek/ statistiky-kriminality-dokumenty.aspx.

\section{Authors}

Mgr. et Mgr. Stanislava Hoferková, Ph.D.

Faculty of Education, University of Hradec Králové Department of Social Pathology and Sociology Rokitanského 62, 500 03, Hradec Králové, Czech Republic Stanislava.Hoferkova@uhk.cz

Mgr. et Mgr. Tereza Raszková Pedagogical Faculty, Palacký University in Olomouc Department of Pedagogy and Social Studies Žižkovo nám. 5, 771 40, Olomouc, Czech Republic Tereza.Longova@seznam.cz 